\title{
Genotype and Phenotype Correlations in Children with Familial Mediterranean Fever
}

\section{Akdeniz Ateşi Olan Çocuk Olgularda Genotip ve Fenotip Karşılaştırlması}

\author{
Sare Gülfem ÖZLÜ1, Müferet ERGÜVEN², Öznur YILMAZ HAMZAH³
}

\author{
${ }^{1}$ Dr Sami Ulus Maternity and Child Health and Diseases, Education and Research Hospital, Pediatric Nephrology and Rheumatology \\ Clinic, Ankara, Turkey \\ ${ }^{2}$ Istanbul Medeniyet University, Göztepe Education and Research Hospital, Department of Pediatric Rheumatology, İstanbul, Turkey \\ ${ }^{3}$ Central Hospital, Department of Child Health and Diseases, İstanbul, Turkey
}

\begin{abstract}
Objective: The aim of this study was to review the demographic, clinical, and laboratory data of pediatric familial Mediterranean fever (FMF) patients, and to investigate whether there is a correlation between phenotype and genotype in this population.
\end{abstract}

Material and Methods: The medical records of 192 children (106 male and 86 female) with FMF who were followed at Department of Rheumatology-İstanbul Göztepe Training and Research Hospital, were retrospectively evaluated. The patients were divided into four groups according to the most common mutations of M680I, M694V, and V726A as follows: group 1: M694V heterozygote; group 2: M694V/M694V homozygote; group 3: compound heterozygote (M694V/M680I or M694VN726A); group 4: group with no mutation. These groups were compared to each other according to age, gender, age at disease onset, age at diagnosis, fever, abdominal pain, arthralgia-arthritis, chest pain, erysipelas-like erythema, disease severity score, amyloidosis and family history.

Results: The disease severity score was higher in the M694V homozygote and compound heterozygote groups than in the group with no mutation, but there was no difference between the M694V homozygote and M694V heterozygote groups.

Conclusion: Although the patient population was small and few mutations were detected in the present study, we conclude that the patients that were homozygous for M694V mutations were prone to severe disease.

Key Words: Children, Familial Mediterranean fever, Genotype phenotype

\section{ÖZET}

Amaç: Çalışmada "Ailevi Akdeniz Ateşi (AAA)" tanısı olan çocuk hastaların demografik, klinik ve laboratuvar Özelliklerinin incelenmesi ve ayrıca gen mutasyonlarının hastalık ağırlık skorlaması üzerine etkisinin araştırıması amaçlanmıştır.

Gereç ve Yöntemler: İstanbul Göztepe Eğitim ve Araştırma Hastanesi, Çocuk Romatoloji polikliniğinde AAA tanısı ile izlenen 192 çocuk hastanın (106 erkek, 86 kı) dosyaları geriye dönük olarak incelendi. Hastalar, en sık rastlanan mutasyonlar olan M694V, M680I ve V726A mutasyonlarının varlığına göre dört gruba ayrıld: grup 1:M694V heterozigot mutasyonu olanlar; grup 2: M694V/M694V homozigot mutasyonu olanlar; grup3: birleşik heterozigot mutasyonu olanlar (M694V/M680I veya M694V/N726A); grup 4: mutasyonu olmayanlar. Bu gruplar yaş, cinsiyet, aile öyküsü, hastalığın başlangıç yaşı, tanı yaşı, ateş, karın ağrısı, artrit-artralji, göğüs ağrısı, erizipel benzeri eritem, amiloi doz varlığı ve hastalık ağırlık skorlaması açısından karşılaştırıldı.

Bulgular: Hastalık ağırlık skorlaması M694V homozigot olan grupta ve birleşik heterozigot olan grupta mutasyon taşımayan gruba göre anlamlı olarak daha yüksek saptandı. M694V mutasyonu homozigot ve heterozigot olan iki grup arasında ise hastalık ağılık skorlaması açısından istatistiksel anlamda fark saptanmadı.

Sonuç: Çalışmada hasta sayısı ve çalışılan mutasyon sayısının az olmasına karşın, homozigot M694V mutasyonu saptanan hastaların daha ağır hastalığa eğilimli oldukları görülmektedir.

Anahtar Sözcükler: Çocuk, Ailevi Akdeniz ateşi, Genotip fenotip 


\section{INTRODUCTION}

Familial Mediterranean fever (FMF) is an autosomal recessive disease that primarily affects Turks, Jews, Armenians, Arabs, and other ethnic groups of the Mediterranean basin, including Greeks, Italians, and Druze $(1,2)$. FMF is characterized by recurrent episodes of fever, abdominal pain, and joint pain, and, less frequently, pleuritis, pericarditis, and rash described as erysipelas-like erythema (3). The gene responsible for FMF, designated as Mediterranean fever (MEFV), was identified by positional cloning and mapped to the short arm of chromosome 16, and its product pyrin/marenostrin was reported to play a pivotal role in the regulation of inflammation (4-7). More than 150 mutations have been described in the MEFV gene, most of which are in exon 10 (8). Among the mutations, 4 in exon 10 and 1 in exon 2 comprise 85\% of the mutations in the geographical regions in which FMF is frequent (8).

FMF is a clinically heterogeneous disease, ranging from mild to devastating disease (9). As evidenced by genotype-phenotype correlations, patients carrying certain mutations are prone to a more severe disease course $(8,10)$. To date, primarily two disease severity scoring systems have been developed mainly for adults $(9,11)$. We used the Pras severity scoring system for the present study to assess disease severity in children. The aim of the present study was to review the demographic, clinical, and laboratory data of pediatric FMF patients, and to investigate the effect of genetic mutations on disease severity score and other clinical and laboratory findings.

\section{MATERIAL and METHODS}

The study included 192 FMF patients (106 males and 86 females) that were followed-up routinely at our outpatient clinic at Göztepe Training and Research Hospital, Istanbul, Turkey. All of the patients were diagnosed as FMF, according to TelHashomer criteria (Table I). Medical records of the patients were investigated retrospectively for sex, age, family history, age at disease onset and diagnosis, fever, abdominal pain, chest pain, arthritis, erysipelas like erythema; whole blood count, serum acute phase reactants, fibrinogen and genetic mutations

DNA analysis was performed at a local reference center. DNA was extracted from peripheral blood lymphocytes via standard procedures and amplified using sequence-specific primers via PCR. Patients were screened for the three most common mutations - M694V, M680I, and V726A.

Disease severity was calculated based on the Pras score and patients were divided into 3 subgroups according to this score: patients with mild disease (score between 3-5), patients with moderatedisease (score between 6-8) and patients with severe disease (score $\geq 9$ ) (Table II).

The patients were classified into four groups according to the common MEFV mutations, as follows: group 1: heterozygote
Table I: Tel-Hashomer criteria for the clinical diagnosis of FMF.

\section{Major criteria}

1- Fever accompanied with peritonitis, pleuritis or synovitis

2- AA type amyloidosis without any predisposition

3- Favourable response to colchicine

\section{Minor criteria}

1- Relapsing attacks of fever

2- Erysipelas like erythema

3- FMF in a first degree-relative

Definitive FMF: 2 major or 1 major 2 minor criteria

Probable FMF: 1 major and 1 minor criteria

Table II: Disease severity scoring system of Pras.

\begin{tabular}{|l|c|c}
\hline Parameter & Features & Score \\
\hline & $>31$ & 0 \\
& $21-31$ & 1 \\
Age of onset (years) & $11-20$ & 2 \\
& $6-10$ & 3 \\
& $<6$ & 4 \\
\hline Number of attacks & $<1$ & 1 \\
& $1-2$ & 2 \\
\hline \multirow{3}{*}{ Arthritis } & $>2$ & 3 \\
\hline Erysipelas-like erythema & Acute & 2 \\
\hline Amyloidosis & Protracted & 3 \\
\hline & & 2 \\
\hline Colchicine dose (mg/day) & 2 & 3 \\
\hline
\end{tabular}

M694V mutation (M694V/-); group 2: homozygote M694V mutation (M694V/M694V); group 3:compound heterozygote mutation; group 4: group with no mutation. Heterozygote M680I and V726A mutations were small in number so they were not included in this classification. Correlation between these mutations, and the Pras severity score, laboratory and clinical findings were evaluated. The study protocol was performed according to the principles of the Declaration of Helsinki and all patients or their parents provided informed consent.

\section{STATISTICAL ANALYSIS}

Statistical analysis was performed using Graph Pad Prisma v.3.0 software. Data were evaluated using descriptive statistical methods (mean $\pm \mathrm{SD}$ ). Inter-group comparison was performed via one-way analysis of variance (ANOVA), sub-group 
comparison via Tukey's multiple comparison test, comparison of 2 groups via the independent samples test, and qualitative data were compared via the chi-square test. The level of statistical significance was set at $p<0.05$.

\section{RESULTS}

\section{Demographic and Clinical Features}

The study included 192 patients (106 male and 86 female) with a mean age of $11.34 \pm 4.29$ years (range: $2.6-19$ years). Mean age at disease onset was $5.34 \pm 2.56$ years and mean age at diagnosis was $8.45 \pm 3.45$ years (range: $2-17$ years). Family history of FMF was positive in $76(39.2 \%)$ of the patients. The parental consanguinity rate was $38 \%(n=73)$.

The most common clinical features during symptomatic episodes of attack were abdominal pain ( $n=186$ [96.87\%]), fever $(n=155$ [80.72\%]), and joint involvement (arthritis-arthralgia) $(n=120$ [62.5\%]). Chest pain $(n=67$ [34.89\%]), myalgia $(n=49$ [25.2\%] and erysipelas like erythema $(n=30$ [15.6\%] were also common clinical findings. In our study, two (1\%) and eight (2.8\%) of our patients had a diagnosis of protracted febrile myalgia and Henoch-Schonlein Purpura respectively before the diagnosis of FMF. Abdominal pain may mimic acute appendicitis and 23 (11.9\%) of our patients (11.9\%) had undergone appendectomy before the diagnosis of FMF. Among the 192 patients, 69.2\% had complete response, $23.4 \%$ had a partial response, and $7.4 \%$ were unresponsive to colchicine treatment respectively. The clinical characteristics of the patients are summarized in Table III.

\section{Acute Phase Reactants}

The erythrocyte sedimentation rate (ESR) and C-reactive protein (CRP) level during symptomatic episodes were highest in the homozygote group. Similarly, the serum fibrinogen levels between episodes were higher in the homozygote group than in the group with no-mutation. (231.89 \pm 50.99 mgdL-1, versus $208.06 \pm 47.01 \mathrm{mg} \mathrm{dL}-1, \mathrm{p}=0.002)$. There were no difference between other groups in respective to fibrinogen levels. In addition, there was no significant difference in the serum fibrinogen level during symptomatic episodes between the homozygote group and group with no mutation.

\section{Genetic Features}

Homozygous M694V mutation was the most common mutation ( $n=62$ [32.3\%]), followed by heterozygous M694V mutation ( $\mathrm{n}$ $=38$ [19.8\%]), M680I homozygous mutation ( $n=8$ [4.2\%]), and V726A homozygous mutation ( $n=1$ [0.5\%]), whereas mutation was not detected in 54 (28.1\%) patients. Other genotypic features are summarized in Table IV.

\section{Disease Severity Score}

The Pras scoring system showed that disease severity was mild, moderate, and severe in 18 (9\%) patients, 158 (84\%), and $14(7 \%)$ respectively. The patients were divided into four groups according to mutations, as described in the Materials and Methods section. There was no correlation between age at diagnosis and mutations. Mean age at disease onset was higher in the M694V/- and compound heterozygous groups than in the group with no mutation. The number of patients with arthritis and erysipelas-like erythema was significantly higher in the M694V homozygote group than in the other mutation groups $(p=0.048$ for arthritis and $p=0.029$ for erysipelas-like erythema). There was no difference for fever, abdominal pain, chest pain, arthralgia, myalgia, scrotal involvement, amyloidosis, or proteinuria between the groups.

Table III: Clinical and demographic features of our patients.

\begin{tabular}{l|c}
\hline Patient number & $\mathbf{1 9 2}$ \\
\hline Age (years \pm SD) & $11.34 \pm 4.29(2.6-19)$ \\
\hline Age of disease onset & $5.34 \pm 2.56(6$ months-15 years, \\
\hline Age of diagnosis & 4 months) \\
\hline Girls/Boys & $86 \pm 3,45(2-12$ years) \\
\hline Fever & $155(80.72 \%)$ \\
\hline Abdominal pain & $186(96.87 \%)$ \\
\hline Joint involvement & $120(62.5 \%)$ \\
(arthritis, arthralgia) & $49(25.2 \%)$ \\
\hline Myalgia & $67(34.89 \%)$ \\
Chest pain & $30(15.62 \%$ \\
Erysipelas like erythema & $12(6.25 \%)$ \\
Vasculitis & $12(6.25 \%)$ \\
\hline Scrotal pain & $29(15.1 \%)$ \\
\hline Proteinuria & $6(2.6 \%)$ \\
Amyloidosis & $20(10.41 \%)$ \\
\hline Amyloidosis in family & $76(39.58 \%)$ \\
FMF in family & $73(38.02 \%)$ \\
\hline Consanguinity & $7.05 \pm 2.10$ \\
\hline Disease severity score & \\
\hline
\end{tabular}

Table IV: Genetic mutations of patients.

\begin{tabular}{|l|c|c|}
\hline Mutation & Number of patients & Percentage \% \\
\hline M694V/M694V & 62 & 32.3 \\
\hline M694V/- & 38 & 19.8 \\
\hline M694V/M680I & 9 & 4.7 \\
\hline M680I/M680I & 8 & 4.2 \\
\hline M694V/V726A & 8 & 4.2 \\
\hline V726/- & 7 & 3.6 \\
\hline M680I/- & 4 & 2.1 \\
\hline V726A/V726A & 1 & 0.5 \\
\hline V726A/M680I & 1 & 0.5 \\
\hline No mutation & 54 & 28.10 \\
\hline
\end{tabular}


Mean Pras disease severity score did not differ significantly between the homozygote M694Vgroup (7.85 \pm 1.95$)$ and heterozygote M694V group (7.04 \pm 2.17$)(p=0.132)$, but was significantly higher in the homozygote M694V group (7.85 \pm 1.95) and in the compound heterozygote group (7.22 \pm 1.48$)$ than in the group with no mutation $(5.81 \pm 2.05)(p=0.001$ and $\mathrm{p}=0.048$, respectively). Among the patients in the homozygote M694V group, 8 (12.9\%), 50 (80.64\%), and 4 (6.45\%) patients had severe, moderate, and mild disease severity scores, respectively.

\section{DISCUSSION}

In the present study the demographic and clinical features of FMF patients were evaluated, and the effect of gene mutations on the disease severity score and other phenotypic features were investigated. As previously reported, there was a male predominance (male-female ratio of 1.23:1), which is consistent with the male-female ratio of 1.2:1 reported by the Turkish FMF Study Group (12). Düşünsel et al. (13) reported that the mean age at disease onset and at diagnosis was $6.8 \pm 3.7$ years and $9.7 \pm 3.7$ years, respectively, which is in agreement with our findings.

The typical clinical findings of FMF vary according to society and ethnicity. Although arthritis is the third most common clinical finding in Jewish patients, pleuritis is more common than arthritis in Armenians $(3,14)$. Studies from Turkey have reported that abdominal pain is the most common symptom, followed by fever, arthritis, pleuritis, and erysipelas-like erythema $(12,15)$. In the present study, the most common clinical symptom was peritonitis (96.9\%), followed by fever (80.8\%), arthritis-arthralgia (62.5\%), pleuritis (34.9\%), and erysipelas-like erythema (15.6\%), which is in agreement with earlier reports from Turkey $(12,15)$.

The incidence of clinical findings in FMF patients can also vary according to genetic mutations. Yalçınkaya et al. (15) reported that the incidence of arthritis was 39\% among patients with homozygote M694V mutation and 47\% in those with heterozygote M694V, whereas Olgun et al. (16) more recently reported incidences of $71 \%$ and $29.4 \%$, respectively. Our findings are compatible with other studies; the incidence of arthritis was $39.4 \%$ in the homozygote M694V group and $20.4 \%$ in the no mutation group, and the difference was statistically significant $(p=0.048)$. In the present study, erysipelas-like erythema was more common in the M694V homozygote group (31\%) than in the group with no mutation (9.3\%) $(p=0.029)$, which is in agreement with Pras et al. (17) who reported that erysipelas-like erythema is more common in FMF patients homozygote for M694V.

Acute abdominal pain is the most common clinical finding in FMF and can mimic appendicitis. Kisacık et al. (18) recently reported establishing FMF in $7.7 \%$ of patients with negative appendectomy. The frequency of appendectomy was reported as $19 \%$ by the Turkish FMF Study Group (12). Similarly, 23 patients (11.9\%) in our study had undergone appendectomy and the number of patients with appendectomy did not differ significantly between the mutation groups ( $p=0.868)$.

Amyloidosis is the most severe complication of FMF and can cause end-stage renal disease (19). The reported incidence of amyloidosis varies according to ethnicity as follows: $1 \%-2 \%$ among Armenians living in the US, 27\% among non-Ashkenazi Jews, 2\% among Arabs, and 12.9\% and 15\% among Turks $(12,20,21)$. Amyloidosis was noted in $2 \%$ of patients in the present study and this was lower than the percentage previously reported from Turkey. This lower percentage may be attributed to the small number of patients in the present study. There was no significant difference regarding the occurrence of amyloidosis between the groups with mutation in our study $(p=0.114)$, and two previous studies from Turkey reported no association between amyloidosis and M694 homozygosity. Some environmental and racial factors might also play a role in the development of amyloidosis (13).

As expected, acute phase reactants were elevated during symptomatic episodes in our study. The ESR and CRP level during episodes were significantly higher in the homozygote M694V group than in the other groups $(p=0.002$ and $p=0.004$, respectively). The serum fibrinogen level was higher both during episodes and symptom-free periods in the homozygote M694V group, as compared to other groups $(p=0.045$ and $p=0.02$, respectively). We argue that this might be associated with a more severe disease course.

A severity scoring system for adult FMF patients was first developed by Pras et al. (11) in 1997 and they reported that the disease course was more severe in M694V homozygote patients (11). Although the Pras scoring system was used for children in the present study, the findings are consistent with those reported earlier. The majority of the patients in the present study ( $n=158$ [84\%]) had a moderate severity score, and the mean disease severity score was significantly higher in the M694V homozygote group and compound heterozygote group than in the group with no mutation $(p=0.001$ and $p=0.048$, respectively), whereas there was no significant difference between the M694V homozygote and M694V heterozygote groups $(p=0.132)$. These findings might indicate that patients with homozygote M694V mutation and compound heterozygote mutation have a more severe disease course, as previously reported $(11,23)$. Nonetheless, as the Pras scoring system is designed for adults, we are aware that there may be some inconsistencies when it is used with children.

Ozen et al. (24) recently reported the effect of environmental factors on disease severity in children and adolescents with FMF. Additionally, Kalkan et al. (25) reported that a new disease severity scoring system must be developed for children with FMF to facilitate assessment of daily care performance or individual patient prognosis and guide care. 
In conclusion, although the diagnosis of FMF is based on clinical findings, molecular studies are important for detecting disease-causing mutations. Although FMF patients with M694V mutation are prone to more severe disease, as indicated in our study, due to small sample size and only 3 mutations studied, the findings must be interpreted with caution. We think that additional research is needed to develop a disease severity scoring system that could be used for pediatric FMF patient.

\section{REFERENCES}

1. Pras M. Familial Mediterranean fever: From the clinical syndrome to the cloning of pyrin gene. Scand J Rheumatol 1998;27:92-7.

2. La Regina M, Nucera G, Diaco M, Procopio A, Gasbarrini G, Notarcnicola C, et al. Familial Mediterranean fever is no longer a rare disease in Italy. Eur J Hum Genet 2004;12:85-6.

3. Sohar E, Gafni J, Pras M, Heller H. Familial Mediterranean fever. A survey of 470 cases and review of the literature. Am J Med1967;43:227-53.

4. Consortium The International FMF. Ancient missense mutation in a new member of the roret gene family are likely to cause Familial Mediterranean fever. Cell 1997;90:797-807.

5. Consortium The French FMF. A candidate gene for Familial Mediterranean fever. Nat Genet 1997;17:25-31.

6. Centola M, Wood G, Frucht DM, Galon J, Aringer M, Farrell C, et al. The gene for Familial Mediterranean fever, MEFV, is expressed in early leukocyte development and is regulated in response to inflammatory mediators. Blood 2000; 95:3223-31.

7. Chaee JJ, Wood G, Richard K, Jaffe H, Colburn NT, Masters $\mathrm{SL}$, et al. Targeted disruption of pyrine, the FMF protein, causes heightened sensitivity to endotoxin and a defect in macrophage apoptosis. Mol Cell 2003;11:591-604.

8. Soriano A, Pras E. Familial Mediterranean fever: Genetic update. IMAJ 2014;16:274-76

9. Simon A, van der Meer JW. Pathogenesis of familial periodic fever syndromes or hereditary autoinflammatory syndromes. Am. J Physiol Regul Integr Comp Physiol 2007;292:R86-98.

10. Mor A, Shinar Y, Zaks N, Langevitz P, Chetrit A, Shtrasburg S, et al. Evaluation of disease severity in familial mediterranean fever. Semin Arthritis Rheum 2005;35:57-64.

11. Pras E, Livneh A, Balow JE Jr, Pras E, Kastner DL, Pras M, et al. Clinical differences between North African and Iraqi Jews with familial Mediterranean fever. Am J Med Genet 1998;13;75:216-19.
12. Tunca M, Akar S, Onen F, Ozdogan H, Kasapcopur O, Yalcinkaya $\mathrm{F}$, et al. Familial Mediterranean fever (FMF) in Turkey: Results of a nationwide multicenter study. Medicine (Baltimore) 2005;84:1-11.

13. Düşünsel R, Dursun I, Gündüz Z, Poyrazoğlu MH, Gürgöze MK, Dündar M. Genotype-phenotype correlation in children with familial Mediterranean fever in a Turkish population. Pediatr Int 2008;50:208-12.

14. Schwabe AD, Peters RS. Familial Mediterranean Fever in Armenians. Analysis of 100 cases. Medicine (Baltimore) 1974;53:45362.

15. Yalçınkaya F, Çakar N, Misirlioglu M, Tumer N, Akar N, Tekin M, et al. Genotype -phenotype correlation in a large group of Turkish patients with familial Mediterranean fever: Evidence for mutation independent amyloidosis. Rheumatology (Oxford) 2000;39:67-72.

16. Olgun A, Akman S, Kurt I, Tuzun A, Kutluay T. MEFV mutations in Familial Mediterranean fever: Association of M694V homozygosity with arthritis. Rheumatol Int 2005;25:255-9.

17. Pras E, Langevitz P, Livneh A. Genotype-phenotype correlation in familial Mediterranean fever (a preliminary report). In: Sohar E, Gafni J, Pras M (eds). Familial Mediterranean Fever. Tel Aviv: Freund Publishing House, 1997:260-4.

18. Kisacik B, Karabicak I, Erol MF, Ozer S, Pehlivan Y, Onat AM, et al. Is familial Mediterranean fever (FMF) common in patients with negative appendectomy. Mod Rheumatol 2013; 23:330-3.

19. Yalçınkaya F, Akar N, Mısırlığlu M. FMF amyloidosis and the Val726Ala mutation. N Engl J Med 1998;338:993-4.

20. Pras M, Bronshpigel N, Zemer D, Gafni J. Variable incidence of amyloidosis in familial Mediterranean fever among different ethnic groups. John Hopkins Med J 1982;150:22-6.

21. Majeed HA, Barakat M. Familial Mediterranean fever in children: Analysis of 88 cases. Eur J Pediatr 1989;148:637-41.

22. Tekin M, Yalçınkaya F, Cakar N, Akar N, Misirlioğlu M, Taştan H, et al. MEFV mutations in multiple families with familial Mediterranean fever: Is a particular genotype necessary for amyloidosis? Clin Genet 2000;57:430-34.

23. Ozalkaya E, Mir S, Sozeri B, Berdeli A, Mutlubas F, Cura A. Familial Mediterranean fever gene mutation frequencies and genotypephenotype correlations in the Aegean region of Turkey. Rheumatol Int 2011; 31:779-84.

24. Ozen S, Aktay N, Lainka E, Duzova A, Bakkaloglu A, Kallinich T. Disease severity in children and adolescents with familial Mediterranean fever: A comparative study to explore environmental effects on a monogenic disease. Ann Rheum Dis 2009; 68:246-8.

25. Kalkan G, Demirkaya E, Acikel CH, Polat A, Peru H, Karaoglu A, et al. Evaluation of the current disease severity scores in paediatric FMF: Is it necessary to develop a new one? Rheumatology 2012;51:743-8. 